\title{
ANÁLISIS DE LA EVOLUCIÓN LEGISLATIVA DE LA PROTECCIÓN DE MENORES EN LA COMUNIDAD AUTÓNOMA DE LA RIOJA
}

\author{
Juan Manuel MURILLAS ESCUDERO \\ PROFESOR DE DERECHO CIVIL \\ UNIVERSIDAD DE LA RIOJA
}

SUMARIO: I. Introducción. II. A qué menores va especialmente dirigida la Ley I/2006, de 28 de febrero, de Protección de Menores de La Rioja. III. Reconocimiento de los derechos fundamentales del menor. IV. De la situación de riesgo. V. De la situación de desamparo. VI. Guarda y acogimiento. VII. Adopción y Registro de Protección de Menores. VIII. Anexo: Enumeración de los derechos y deberes de los menores en los Centros de acogida. IX. Bibliografía. X. Legislación.

Resumen: Se pretende realizar un análisis de los aspectos más importantes que incorpora la Ley I/2006, de 28 de febrero de 1996, de Protección de Menores de La Rioja, resaltando las novedades respecto a la ley anterior (Ley autonómica 4/1998, de i 8 de marzo, del menor, vigente hasta el 9 de septiembre de 2006), exponiendo una breve exposición sobre los derechos fundamentales del menor, y considerando especialmente las situaciones de riesgo y desamparo de los menores.

PALABRAS ClAVE: interés superior del menor, riesgo, acogimiento, desamparo, tutela automática.

\section{ANALYSIS OF THE LEGISLATIVE FUNCTION OF THE PROTECTION OF MINOR IN LA RIOJA REGION}

ABSTRACT: It intends to carry out an analysis of the most important aspects than incorporates the Law I/2006, of February 28, I996, of Protection of minors in The Rioja, standing out the news with respect to the previous law (autonomous Law 4/1998, of I8 of March, of the smaller one, in force until September 9, 2006), exposing a brief exposition on the fundamental rights of the smaller one, and considering especially the situations of risk and Desertion of the smaller.

KEYwORDS: upper interest of the minor, risk, placement, abandonment, automatic tutelage.

\section{Introducción}

Ha sido una constante en la historia de la humanidad la existencia de menores desasistidos de las necesidades más elementales, bien por fallecimiento o ausencia de sus progenitores, bien por incapacidad o imposibilidad de atenderlos, o bien por otras 
circunstancias, de tal manera que se han encontrado indefensos a lo largo de la historia y carentes de las necesidades más básicas para subsistir. Sin embargo, nunca hasta fechas recientes ha sentido el Ordenamiento jurídico, y muy especialmente el Derecho Civil, la necesidad de abordar desde un tratamiento unitario y sistemático la protección jurídica del menor.

Con la vista puesta en el siglo XX queremos dejar constancia de la primera Declaración de Ginebra de I924 sobre los Derechos del Niño, adoptada en el marco de la Sociedad de Naciones. La pieza fundamental en la moderna concepción de la protección de menores es la Declaración de los Derechos del Niño aprobada el 20 de noviembre de 1959 por la Asamblea General de las Naciones Unidas, estableciendo una serie de derechos que progresivamente se van incorporando a la legislación de los diferentes Estados miembros. En esta Declaración aparece por primera vez formulado el principio del interés superior del niño.

Completando esta Declaración se aprueba el 20 de noviembre de 1989 la Convención sobre los Derechos del Niño, en la cual se destaca y se considera primordial el interés superior del niño que habrá de tenerse en cuenta en lo sucesivo en todas las medidas que adopten las instituciones públicas o privadas de bienestar social, los tribunales, las autoridades administrativas o los órganos legislativos, comprometiéndose todos los Estados a adoptar todas las medidas administrativas, legislativas y de otra índole para dar efectividad a los derechos reconocidos en aquella Convención, arts. 3 y 4, aunque bien es cierto y por no ser exhaustivos citando diferentes leyes, en nuestro país con anterioridad a esa fecha, ya se venían observando esas directrices, como ejemplo únicamente la Ley 8/ı980, de io de marzo, -actualmente Real Decreto Legislativo i/95, de 24 de marzo, Texto Refundido de la Ley del Estatuto de los Trabajadores- que garantiza el derecho de los menores a ser protegidos contra toda forma de explotación en el trabajo, prohibiendo expresamente el trabajo de menores de dieciséis años.

El carácter intervencionista del Estado moderno en numerosos aspectos de la vida de sus ciudadanos, también tiene su reflejo directo en la situación de los menores abandonados o en desamparo, por ello debemos tener presente la influencia de la Constitución de $1978^{\mathrm{I}}$ sobre el régimen legal de tutela en la protección de menores desamparados, así se aprueban sucesivamente las Leyes II/ı98I, de I3 de mayo (reforma de la incapacitación, tutela y curatela) y I3/1983, de 24 de octubre, (de reforma del Código Civil en materia de tutela), aunque las mayores innovaciones en esta materia vinieron por la reforma operada en el Código civil por la Ley 2I/1987, de in de noviembre, que instauró un nuevo sistema de protección a los menores, modificando determinados artículos del Código civil y de la Ley de Enjuiciamiento Civil en materia de adopción, además de atribuir competencia en la materia a entidades públicas administrativas y, posteriormente, la incidencia que en el ámbito de esta materia tiene la Ley Orgánica I/I996, de I5 de enero, de Protección Jurídica del Menor, que insiste en el principio del interés superior del menor, sin olvidar la reciente aprobación de la Ley 54/2007, de 28 de diciembre, de Adopción internacional, que en su Disposición final primera ha introducido diversas modificaciones en el Código Civil, especialmente, ha adicionado dos nuevos apartados séptimo y octavo al art. I72, que serán contemplados cuando abordemos el desamparo del menor.

Actualmente se puede decir que en nuestro Ordenamiento jurídico tenemos una gran cantidad de normas que reconocen todo tipo de derechos a los menores, unas de ámbito internacional, otras nacional y otras autonómico. En el ámbito de la Comunidad Autónoma de La Rioja la actual Ley i/2006, de 28 de febrero, de Protección de Menores, (BOR 9-03-2006), el Decreto 3I/2007, de 25 de mayo, por el que se aprueba el Reglamento

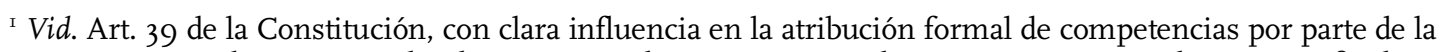
Administración en el sistema tutelar de protección de menores, que plasma posteriormente la Ley 2I/I987 de II de noviembre.
} 
de Intervención Administrativa en Materia de Adopción (BOR 29-05-2007) y el Decreto I08/2007, de 27 de julio, por el que se aprueba el Reglamento sobre intervención de las Administraciones Públicas de La Rioja en la protección y guarda de los menores (BOR 3I07-2007).

A la vista de la profusión de normas de protección, desde el plano normativo todo está muy bien, pero la realidad es que en la práctica el reconocimiento de esos derechos de los menores dependerá de la correcta aplicación que tanto la administración pública, (situaciones de riesgo, acogimiento y desamparo), como los padres (patria potestad), y los responsables de los menores (tutores, guardadores) hagan de tales normas.

\section{A qué menores va especialmente dirigida la Ley $1 / 2006$, de 28 de febrero, de Protección de Menores de La Rioja}

El Estatuto de Autonomía de La Rioja en su redacción originaria por Ley Orgánica 3/1982, de 9 de junio, atribuyó a la Comunidad Autónoma la competencia exclusiva en materia de asistencia social, art. 8.I.I8, que comprende la protección de menores, y para dar curso a esta protección se dictó la Ley autonómica 4/I998, de I8 de marzo, del menor, vigente hasta el 9 de septiembre de 2006. El actual Estatuto de la Comunidad en la redacción recibida tras la Ley orgánica 2/I999, de 7 de enero, mantiene la atribución a la Comunidad Autónoma de la competencia exclusiva en la materia genérica de asistencia y servicios sociales, art. $8^{\circ}$.I.32. Estos últimos preceptos son los que constituyen el fundamento competencial de la actual Ley I/2006, de 28 de febrero, de Protección de Menores de La Rioja.

Conviene llamar la atención sobre la existencia de dos grupos de menores: por una parte, los que están favorecidos por estar protegidos por unos progenitores que desean lo mejor para sus hijos, los educan y respetan como personas en una progresiva formación integral; para este grupo de menores esta Ley del Menor es innecesaria, porque pertenecen a ese grupo de menores afortunados que conviven con unos adultos que los protegen y les reconocen todos sus derechos de persona en formación, sin necesidad alguna de reclamarlos. Esto no quiere decir que en muchas ocasiones se produzcan tensiones de cierta intensidad, pero no especialmente graves para unos menores que viven y se desarrollan en un entorno familiar estructurado que vela por ellos, los tiene en su compañía, los educa y les proporciona una formación integral. Para este grupo de menores, no es necesaria esta ley.

Por el contrario, tenemos otro grupo de menores para los cuales se hace imprescindible la existencia de la ley, para que las consecuencias derivadas del incumplimiento de los deberes inherentes al correcto ejercicio de la patria potestad de los adultos respecto a los menores, se vea mitigado por la aplicación de esta ley. Este segundo grupo de menores ha originado la necesidad de un Derecho del menor, con unas instituciones propias según sea el grado de alcance de desamparo del menor, con un incumplimiento de las obligaciones de los titulares de la patria potestad meramente temporal y corregible en un plazo más o menos largo, o permanente, y sea imposible el cumplimiento de los deberes de la patria potestad, por razones objetivas de carácter definitivo.

Pero al lado de estas situaciones descritas por el mal cumplimiento de los padres de sus obligaciones respecto a sus hijos, no se puede omitir la existencia de otras circunstancias en la formación del menor de edad, más difíciles de tratar por existir un grado de voluntariedad inicial por parte del menor, como son los «menores inadaptados, o drogadictos, o delincuentes, o fugados de su domicilio». Desde algún sector sociológico, se ha manifestado que todos esos grupos de menores se encuentran encuadrados en los 
menores que han sido objeto de «desamparo» por sus progenitores, pero entendemos que no siempre es así, porque al inculpar sistemáticamente a los padres, se olvida la existencia de otros menores que han emprendido ese camino sin aparente justificación alguna procedente de sus padres.

Pasando al análisis de la Ley de La Rioja, en lo sucesivo Ley I/2006, lo primero que nos llama la atención es su extensión, ya que la integran I27 artículos y diferentes Disposiciones. Probablemente haya sido el afán del legislador para que los instrumentos y las instituciones públicas de protección de menores, den respuesta a todas las situaciones de riesgo y desprotección en que éstos pudieran encontrarse, respetando plenamente sus derechos e intereses.

La pretensión de este trabajo no es hacer un comentario sistemático a la ley artículo por artículo, sino resaltar las novedades más relevantes respecto a la anterior ley del Menor de I998, y, destacar los aspectos mas interesantes de la actual. Por ello, iniciando el estudio de la Ley I/2006, el Título Preliminar es de gran importancia. Consta de seis artículos. Describe el objeto, los sujetos a los que se aplica y las competencias de la Administración de la Comunidad Autónoma de La Rioja, a través de la Consejería que asume los Servicios Sociales. En este Título Preliminar destacan diversas novedades importantes que introduce la actual ley respecto a la de 1998.

La primera novedad interesante en el Título Preliminar de la nueva ley, es la eliminación del contenido del anterior art. 4 que contemplaba de forma conjunta en el citado artículo las situaciones de riesgo, de desamparo y de inadaptación del menor, siendo situaciones diferentes con hechos distintos y que deben tener un tratamiento diferenciado. Para seguir una sistemática adecuada con la nueva ley, en el artículo correspondiente de la Ley I/2006, volveremos a tratar estas situaciones.

La segunda novedad importante en el Título Preliminar de la Ley I/2006, es el contenido del art. 5, ya que desde el inicio del texto, fija los principios rectores de la actuación administrativa. Significativo es su contenido, plasmado en el interés superior del menor, integración de los menores en su medio familiar, subsidiariedad de la administración respecto a los deberes de asistencia y protección que compete a los padres y tutores, y defensa de los derechos de los menores reconocidos por la Constitución, los acuerdos internacionales y la Ley Orgánica I/1996, de I5 de enero, de Protección Jurídica del Menor.

\section{Reconocimiento de los derechos fundamentales del menor}

La Ley del Menor de 1998 en la Sección II sobre los Derechos del menor, contemplaba los derechos del menor en los artículos 8 a 3I. Detallaba una enumeración exhaustiva de los derechos fundamentales del menor (prohibición de discriminación, derecho de conciencia y religión, derecho al honor, a la intimidad y a la propia imagen, libre desarrollo de la personalidad, derechos económicos y laborales, etc.). Era una enumeración larga, innecesariamente extensa si consideramos que los poderes públicos han de garantizar los derechos de todas las personas, no sólo de los menores. Además en nuestro Ordenamiento jurídico ya existen numerosas referencias de protección al menor, desde la Constitución hasta el Código Civil, sin olvidar los diversos Convenios y Tratados Internacionales de protección del menor, muy especialmente, la ya citada Convención de los Derechos del Niño, adoptada por la Asamblea General de Naciones Unidas, el 20 de noviembre de I989, ratificada posteriormente por España el 30 de noviembre de I990, formando parte del ordenamiento jurídico nacional en virtud del art. 96 de la Constitución y I.5 del CC., y que «se trata de un verdadero Código universal sobre el menor, que rebasa con creces los propósitos de cualquier Constitución sobre esta materia y, por supuesto, de los códigos civiles» (Alonso Pérez I997, 20). 
La Ley I/2006 ha mejorado sensiblemente este apartado, hace un reconocimiento de los derechos fundamentales del menor (no podía ser de otra manera), pero de forma más simplificada y, a la vez, incorporando novedades importantes. En el Título I, Capítulo II, en los artículos 9 a 20 se contemplan los derechos del menor. Una especialidad interesante es la incorporación en el art. 9 de las garantías necesarias para identificar al recién nacido, así como garantizar el deber de reserva y confidencialidad a las autoridades, funcionarios, profesionales y cualesquiera personas que intervengan en los procedimientos de protección de menores, asumiendo la Administración Pública la vigilancia para el estricto cumplimiento de esta obligación.

En este reconocimiento y protección de los derechos del menor, especialmente significativo, es el art. I6.I.c) «Derecho a la educación» del menor. En este punto es digno de resaltar respecto a la ley de I998, la obligación que asume la Administración garantizando la asistencia y formación específicas a los menores con necesidades educativas especiales (refiere a razones socioeconómicas, culturales, geográficas, físicas, psíquicas, sensoriales o de cualquier otra índole), prestando especial interés a la asistencia del menor a un centro escolar. Contempla la ley la posibilidad de promover programas y acciones específicas encaminadas a erradicar el absentismo escolar del menor. Otra novedad importante respecto a la legislación anterior es la obligación que asume la Administración de proporcionar los medios personales y materiales que sean necesarios para asegurar el derecho a la educación de menores, que por una enfermedad no puedan seguir regularmente el curso en el centro escolar, con independencia de que el menor esté o no esté hospitalizado.

Si anteriormente he comentado la importancia del Título Preliminar, ahora, en el capítulo de los derechos del menor que se están contemplando, debemos subrayar esta relevancia. Decimos esto porque el art. 2.2 indica a quiénes se aplica esta ley, y señala a todos los menores que residan o se encuentren en la Comunidad Autónoma de La Rioja, independiente de su nacionalidad o vecindad. Posteriormente el legislador desarrolla este texto en el capítulo de los derechos del menor, en el art. I9, «Derecho a la integridad social». Su punto 2, es muy minucioso y especialmente interesante promoviendo los medios que sean necesarios para facilitar la integración social, lingüística, cultural, respetando su propia identidad, considerando los valores de otras culturas, con una única limitación que impone el legislador: que aquellos valores culturales no menoscaben el orden público constitucional. Es especialmente relevante este artículo por la previsión de futuro que hace el legislador, si atendemos a la situación actual y futura de una sociedad en un mundo cada vez más globalizado y multicultural.

El Capítulo III del Título I, sobre la protección del menor frente a determinadas actividades, medios y productos, está muy bien articulado respecto a la legislación anterior. En la anterior ley llamaban la atención los artículos 27, 28 y 29, que suponían una novedad tanto respecto a la LO. I/1996, como a las demás leyes autonómicas que regulaban la materia.

Art. 27: «La exhibición o emisión pública de imágenes, mensajes u objetos, no pueden ser perjudiciales para los menores, ni incitar a actitudes o conductas que vulneren los derechos $y$ principios reconocidos por la Constitución y el resto del ordenamiento jurídico vigente».

Art. 28: «Las publicaciones que incitan a la violencia, a actividades delictivas o a cualquier forma de discriminación, o tengan un contenido pornográfico, o cualquier otro que resulte perjudicial para el desarrollo de la personalidad de los menores, no pueden ser ofrecidas ni expuestas de manera que queden libremente a su alcance». 
Art. 29: «No se permite vender ni alquilar a menores vídeos, videojuegos o cualquier otro material audiovisual que contengan mensajes que directa o indirectamente, sean contrarios a los derechos $y$ libertades fundamentales reconocidos por el vigente ordenamiento jurídico, que inciten a la violencia $y$ a actividades delictivas, a cualquier forma de discriminación o que tengan contenido pornográfico. No se permite tampoco proyectarlos en locales o espectáculos en los que se admita la asistencia de menores, ni difundirlos por cualquier medio entre éstos».

Sin embargo, la Ley I/2006, detalla con mayor rigor y precisión las actividades prohibidas a los menores, véase el art. 22, y una novedad interesante es el art. 23, prohibiendo expresamente la venta de tabaco, alcohol y otras sustancias nocivas. Respecto a la prohibición de acceder por cualquier medio a publicaciones audiovisuales que sean perjudiciales para el menor (incitación a la violencia, realización de actividades delictivas, contenidos que inciten a la discriminación, contenidos pornográficos), está recogida en el art. 24 , sin las reiteraciones que contenía la ley anterior. Y el art. 25 regula la emisión de programas de radio y la difusión de imágenes en televisión. Especialmente relevante es el apartado a) evitar escenas y mensajes que fomenten el odio, el desprecio o la discriminación por motivos de nacimiento, sexo, religión, nacionalidad, opinión y cualquier otra circunstancia personal o social.

Esta protección dispensada, es extensible a la publicidad dirigida a menores, art. 26 de la ley. Ahora bien, para aquellos programas que se emitan y puedan ser susceptibles de perjudicar el desarrollo psicológico o moral de los menores, se establece una limitación horaria en su emisión: de las veintidós horas a las seis horas del día siguiente. El cumplimiento de esta norma es evidente que únicamente podrá alcanzar su aplicación a las emisiones o cadenas de televisión que dependan de la Comunidad Autónoma de La Rioja.

No obstante, debemos preguntarnos ¿quién decide y en razón a qué criterios se va a considerar, que es perjudicial o no para el menor la emisión pública de imágenes, mensajes $u$ objetos? ¿Quién determina lo que es respetable, o bien, es una conducta que incita a la vulneración de los derechos y principios reconocidos en la Constitución, y el resto del ordenamiento jurídico vigente?

La respuesta está en la Ley Orgánica I/1996. El art. 5.2 protege al menor de recibir una información que le perjudique o vulnere los principios constitucionales, su texto: «Los padres o tutores $y$ los poderes públicos, velarán porque la información que reciban los menores, sea veraz, plural $y$ respetuosa con los principios constitucionales». Y el art. 5.3, párrafo $2^{\circ}$, hace responsable a las entidades públicas competentes en materia de protección de menores, para que estén vigilantes en la información dirigida a éstos, señala: «En particular, velarán porque los medios de comunicación en sus mensajes dirigidos a menores, promuevan los valores de igualdad, solidaridad $y$ respeto a los demás, eviten imágenes de violencia, explotación en las relaciones interpersonales o que reflejen un trato degradante o sexista».

Aunque ya nos hemos referido a esta cuestión, y somos conscientes de las dificultades de alcanzar virtualidad práctica esta normativa, dado que esta protección alcanza a las emisoras de radio y televisión de las que sea titular la Comunidad Autónoma de La Rioja, no así al resto de emisoras y canales de televisión existentes en el territorio nacional.

También es una novedad en la actual ley respecto a la Ley de I998, el art. 27, obligando a los centros abiertos al público con acceso a la red Internet, que deben disponer los medios necesarios para impedir el acceso a los menores a contenidos que puedan ser perjudiciales para su desarrollo integral. Son muy buenos propósitos con muchas dificultades para que realmente se lleve a cabo, quizá, al final, todo dependa del puro voluntarismo de las personas encargadas de estos establecimientos. 
Queremos destacar el art. 3I, que obliga al Consejo Riojano de Servicios Sociales a remitir anualmente al Gobierno y al Parlamento de La Rioja, un informe sobre las denuncias recibidas que vulneren los derechos del menor y las prohibiciones establecidas en la ley, y las actuaciones realizadas que a la vista de estas denuncias ha realizado el órgano competente de la Administración de la Comunidad Autónoma de La Rioja.

En el ámbito de la prevención ordena la ley que los cuidados y asistencias especiales también tengan su aplicación «antes de nacer», art. 32.4. Previendo que el nacido se encuentre en una situación de desamparo, obliga a la Administración a que tome las medidas necesarias para paliar esta situación. Es muy delicada esta protección que obliga la ley a los Servicios Sociales, porque, evidentemente, la situación prevista (desamparo del recién nacido) en términos literales de la ley y las circunstancias del niño, obliga a cuidar al recién nacido en un ámbito familiar, y éste no puede ser otro que la adopción del menor, con todas las dificultades que pueden surgir ante la madre biológica.

\section{De la situación de riesgo}

Nos vamos a centrar ahora en las medidas de protección del menor, que verdaderamente constituyen el núcleo fundamental y la razón de existir de esta ley. Las actuaciones en situaciones de riesgo vienen señaladas en el art. I7 de la LO. I/ı996. Este artículo se limita a señalar que en situaciones de riesgo que perjudiquen el desarrollo personal o social del menor, pero que no revistan una gravedad que haga necesaria la asunción de la tutela por parte de la Administración pública, los poderes públicos deberán orientar su función a disminuir los factores de riesgo y promover los factores de protección del menor en su entorno familiar².

Al no estar contemplada la situación de riesgo en el Código Civil y no estar regulados sus efectos jurídicos, aunque no altera las funciones de patria potestad que tienen los padres, el art. I7 de la LO. I/I996 propone en estas situaciones una actuación claramente administrativa y asistencial. Es verdad no obstante, que su art. Io, apartado b), garantiza la intervención del Ministerio Fiscal cuando éste tenga conocimiento por cualquier medio de una situación de riesgo para el menor, y que puede promover las acciones oportunas, pero es evidente que aquí el legislador, con muy buen criterio, ha dejado plena autonomía a las Comunidades Autónomas, para que sean ellas las que individualicen y personalicen para cada Comunidad las medidas a adoptar.

En este sentido, la Ley I/2006 cumple perfectamente sus funciones, articulando en el Capítulo II, Título II, artículos 40 a 47, la prevención de situaciones de riesgo y las medidas a seguir en las diferentes situaciones. Es importante reseñar el carácter prioritario que otorga la ley a la actuación pública, tendente a la prevención de los factores de riesgo que incidan negativamente en el menor, que en un sentido amplio abarcará una actuación integral que contemple la carencia económica de la familia como factor de riesgo para el menor, aplicando medios para mejorarla, y, por otra parte, se deberá prestar especial atención a la situación social del entorno del menor; y en un sentido restringido, contempla la prevención como medida de protección de menores, articulada a través de actuaciones concretas de ayudas a las familias o personas bajo cuya responsabilidad se encuentre el menor, evitando una situación de máximo riesgo como es el desamparo33.

La naturaleza administrativa de la prevención del riesgo viene reflejada en el art. 4I.I de la Ley, que literalmente dice: «La situación de riesgo ha de ser declarada mediante

\footnotetext{
${ }^{2}$ La Exposición de Motivos de la Ley Orgánica, señala que «(...) la citada intervención se limita a eliminar, dentro de la institución familiar, los factores de riesgo (...)».

3 Sobre la prevención de las situaciones de desprotección, véase, González Lázaro (2002, 350-35I).
} 
resolución motivada y expresa dictada por el titular de la Consejería a propuesta del que lo sea de la Dirección General competente en materia de protección de menores».

A continuación enumera las medidas a adoptar, teniendo como columna vertebral de las mismas el mantenimiento del menor en el seno familiar, siempre prioritario frente a otras actuaciones, a través de prestaciones económicas o en especie a las familias que carezcan de los recursos suficientes para cubrir las necesidades más básicas de los menores, ayuda a domicilio mediante servicios de orden educativo o psicosocial, incidiendo nuevamente en orden a mantener el hogar familiar como soporte básico de desarrollo integral del menor, y la intervención técnica de los profesionales para la consecución del adecuado ejercicio de las funciones parentales.

La ley deja claro que todas estas funciones de apoyo familiar podrán prestarse simultáneamente, si las circunstancias que las originan inciden conjuntamente sobre el menor. El art. 46 contempla el seguimiento y la ejecución de las medidas que se hayan adoptado, y finalmente, el art. 48 contempla una novedad interesante respecto a la ley anterior, como es la declaración de riesgo sobre menores emancipados y habilitados de edad cuando carezcan de medios materiales de subsistencia o concurran circunstancias que puedan prever una situación de inadaptación del menor.

Todas las medidas adoptadas deben estar encaminadas, además de a satisfacer las necesidades básicas del menor, a procurar su integración social y laboral. Este completo sistema institucional de prevención de situaciones de riesgo y de apoyo familiar, está muy bien descrito en la ley, pero hay que tener presente que para llevarlas a efecto en hechos concretos, es necesario acompañarlas de una importante dotación de medios económicos y personales.

\section{De la situación de desamparo}

El Capítulo III, «De la situación de desamparo y la tutela de la administración», está muy bien articulado. El legislador en únicamente 8 artículos, del 49 al 56, ha elaborado un interesante y adecuado sistema de protección de menores que se encuentren en situación de desamparo. Se inicia con las causas que dan lugar a la declaración de desamparo por la entidad pública, el deber de denuncia que tiene cualquier persona que tenga conocimiento de una situación de desamparo de un menor y pasa a ofrecer las alternativas de solución.

Si uno de los pilares básicos de esta ley, es determinar las circunstancias que han concurrido en esa situación límite de desprotección del menor, proponer soluciones, y finalmente asumir la Administración la tutela automática del menor, es muy de agradecer que todo ello se estructure en 8 artículos. No obstante, consideramos que hubiese sido mejor iniciar este capítulo con el contenido del art. 52, que en su punto I señala que, por imperativo legal, la Comunidad Autónoma de La Rioja a través del órgano competente, asume la tutela de todos los menores que se encuentren en situación de desamparo, detallando en su punto 2 las obligaciones que asume la Administración Pública a través de la Consejería competente de Servicios Sociales respecto a estos menores. Sin embargo, se inicia en el art. 49 que enumera las causas que dan lugar al desamparo, pero no ofrece el concepto de desamparo y remite en este aspecto al Código Civil (art. I72) para su conocimiento.

Atendiendo al art. I72.I CC. es una situación que se produce de hecho a causa del incumplimiento, o del imposible o inadecuado ejercicio de los deberes de protección establecidos por las leyes para la guarda y educación de los menores, cuando éstos queden privados de la necesaria asistencia moral o material. Estamos ante una situación de riesgo del menor o desprotección de tal gravedad que es necesario extraer al menor de su ámbito 
familiar o de las personas que tienen la responsabilidad de su guarda y ponerlo bajo la tutela de la Administración.

Importante aspecto legal del desamparo es que no necesita declaración judicial -ya que es una resolución de naturaleza administrativa-, ni un plazo de duración determinado, que es apreciado por las autoridades públicas competentes que tienen a su cargo la protección de menores y que deberán notificar a los padres, y, en su caso, a los tutores y guardadores de hecho, en un plazo de 48 horas, mediante resolución motivada, expresando de modo comprensible y claro las causas que han llevado a intervenir a la Administración, así como los efectos que produce. La consecuencia más importante en el ámbito familiar, es la suspensión de la guarda del menor de quienes ostenten la responsabilidad parental, pasando la tutela del menor bajo la responsabilidad de las instituciones de protección de menores de la Comunidad Autónoma de La Rioja.

Respecto si debe considerarse extinguida o suspendida la patria potestad o tutela anteriormente existente, aunque en un principio la doctrina encontró ciertas dificultades sobre este punto ${ }^{4}$, las dificultades de interpretación fueron definitivamente superadas y, atendiendo a la naturaleza y funciones que tiene esta tutela automática, se produce una suspensión de hecho y de derecho de la patria potestad o tutela o guarda existente, pero no se produce una extinción. Un argumento elemental pero de suma importancia que avala esta opinión es el probable arrepentimiento de los padres o guardadores, respecto a la desatención o abandono que sufre el menor, o bien un cambio de las circunstancias que en $\mathrm{su}$ momento concurrieron en los padres o responsables del menor y que supuso la intervención de la Administración.

A estos padres, a los cuales se les ha suspendido la patria potestad, de momento solamente podrán «ir a visitar» a sus hijos, pero se pudiera plantear la posibilidad de revocación de la tutela administrativa, la recuperación de la patria potestad y las funciones tutelares de los padres biológicos, con la consiguiente extinción de la tutela administrativa.

Este «arrepentimiento» en la conducta de los padres biológicos, puede acarrear importantes conflictos en los derechos del menor, cuando se produce una colisión de derechos entre la familia acogedora y los padres biológicos. Es evidente que los padres biológicos que han incumplido las obligaciones paternofiliales, van a reclamar su primacía biológica de la paternidad; esta situación llega al límite cuando existen unos padres «acogedores» que con su conducta adecuada, se encuentran realmente más enraizados en el afecto del menor acogido, siendo este interés más digno de protección y de acertada proyección hacia el futuro del menor que el acto generativo biológico. Si damos preferencia a los padres biológicos, pudieran verse sometidos a una grave crisis los derechos del menor por una controvertida prevalencia, propiciada por la ley, de los derechos biológicos del padre o de la madre, obligando al menor a restablecer la convivencia con su «familia natural o biológica», con la posibilidad en muchos casos de la puesta en peligro de los derechos del menor, fundamentalmente el derecho que tiene a un desarrollo integral y adecuado de su personalidad.

Por consiguiente, el derecho de los padres biológicos no debe ser reconocido como principio absoluto cuando se trata de adoptar medidas de protección respecto de un menor desamparado y tampoco debiera tener carácter de derecho o interés preponderante, porque lo que debe prevalecer siempre es el interés del menor. En la jurisprudencia constitucional son constantes las referencias al superior interés del menor, frente al interés de los progenitores biológicos (entre otras, STC 58/2008, de 28 de abril). La adecuación al interés del menor es, así, el punto de partida y el principio en que debe fundarse toda actividad que

\footnotetext{
${ }^{4}$ A favor de la extinción, entre otros autores, Ruiz-Rico Ruiz (i988, 57 y ss.; y 137 y ss.); Valladares Gascón (I990, 204I y ss.); y Martínez de Aguirre (I992, I39I y ss., y I479); a favor de la suspensión, Pérez Álvarez (1989, 92).
} 
se realice en torno a la defensa y a la protección de menores. La medida que se adopte respecto del menor debe ser la que resulte más favorable para el desarrollo físico, intelectivo e integración social del menor y, en su caso, si esto se consigue con un posible retorno a la familia natural, no debe de manera alguna excluirse, pero este retorno no será aceptable cuando no resulte compatible con las medidas más favorables al interés del menor 5 .

Para acordar el retorno del menor desamparado a la familia biológica no basta con una evolución positiva en el comportamiento de los padres biológicos, ni con su propósito de desempeñar adecuadamente el rol paterno y materno, sino que es menester que esta evolución, en el plano objetivo y con independencia de las deficiencias personales o de otro tipo que pudieran haber determinado el desamparo, se vea suficiente y con una continuidad en el tiempo para restablecer la unidad familiar en condiciones que suponga la eliminación del riesgo de desamparo del menor si se han mantenido las referencias parentales con su familia biológica, y si este retorno al ámbito familiar biológico no comporta riesgos relevantes de tipo psíquico para el menor.

En nuestro Ordenamiento jurídico son distintas normas las que declaran que cuando concurran otros intereses legítimos en litigio, se buscará y prevalecerá siempre el interés superior del menor y su reinserción en su propia familia. El principio de reinserción está proclamado en la Declaración de la Asamblea General de las Naciones Unidas, de 3 de diciembre de I986, sobre los principios sociales y jurídicos relativos a la protección y el bienestar de los niños, con particular referencia a la adopción y la colocación en hogares de guarda, en los planos nacional e internacional, y en la Convención de las Naciones Unidas sobre los Derechos del Niño, de 20 de noviembre de I989, ratificada por España el día 30 de noviembre de I990, y ha sido reconocido, en relación con los derechos de los padres biológicos, por el TC a partir de la Sentencia 298/1993, de I8 de octubre. Basta citar el art. I72.4 CC y el art. 2 y II.2 de la LO I/I996, sin olvidar la densa normativa autonómica que sobre esta materia se ha manifestado en esta línea.

Aunque son fundamentales, los arts. 3.I y 9.I de la Convención sobre los Derechos del Niño, de 20 de diciembre de I989. El art. 3.I que dice: «en todas las medidas concernientes a los niños que tomen las instituciones públicas o privadas de bienestar social, los tribunales, las autoridades administrativas o los órganos legislativos, tendrán una consideración primordial a que a lo que se atenderá será el interés superior del niño». Por su parte el art. 9.I señala: «Los Estados Partes velarán porque el niño no sea separado de sus padres contra la voluntad de éstos, (...) añadiendo la excepción, que, salvo que las autoridades competentes determinan, de conformidad con la ley, y los procedimientos aplicables, que tal separación es necesaria en el interés superior del menor».

De todas formas es importante resaltar que para evitar situaciones donde concurran intereses en litigio, posiblemente todos legítimos (tanto de padres como de acogedores, incluso llegando al límite, en acogedores preadoptivos), es importante tener en cuenta la reforma operada mediante la modificación del Código Civil por la Ley 54/2007, de 28 de diciembre de Adopción internacional (BOE, 29 de diciembre, $\mathrm{n}^{\circ}$ 3I2). La Disposición final primera, en su apartado tres, ha modificado el art. I72 CC, concretamente los apartados 3 y 6 y se han adicionado dos nuevos apartados, $7^{\circ}$ y $8^{\circ}$.

Art. I72.7 CC, señala: «Durante el plazo de dos años desde la notificación de la resolución administrativa por la que se declare el desamparo, los padres que continúen ostentando la patria potestad pero la tengan suspendida conforme a lo previsto en el número 1 de este artículo, están legitimados para solicitar que cese la suspensión y quede revocada la declaración de

\footnotetext{
${ }^{5}$ Muy interesante sobre esta cuestión es la STS de 3I julio 2009 (RJ 2009/458I) que en su 6 FD realiza lo que literalmente califica la ponderación del interés del menor en relación con la posible reinserción en la familia biológica. Este fundamento ha sido la ratio decidendi para casar la SAP de Toledo, de 2I noviembre 2006, y que había dado la razón a la madre biológica en su impugnación.
} 
desamparo del menor, si por cambio de las circunstancias que la motivaron entienden que se encuentran en condiciones de asumir nuevamente la patria potestad.

Igualmente están legitimados durante el mismo plazo para oponerse a las decisiones que se adopten respecto a la protección del menor.

Pasado dicho plazo decaerá su derecho de solicitud u oposición a las medidas que se adopten para la protección del menor. No obstante, podrán facilitar información a la entidad pública y al Ministerio Fiscal sobre cualquier cambio de las circunstancias que dieron lugar a la declaración de desamparo».

Por su parte el punto 8, señala: «La entidad pública, de oficio, o a instancia del Ministerio Fiscal o de persona o entidad interesada, podrá en todo momento revocar la declaración de desamparo y decidir la vuelta del menor con su familia si no se encuentra integrado de forma estable en otra familia o si entiende que es lo más adecuado en interés del menor. Dicha decisión se notificará al Ministerio Fiscal».

También la Ley 54/2007, de 28 de diciembre, de adopción internacional, en la Disposición adicional segunda ha modificado determinados artículos de la LEC. Por ser de nuestro interés en la materia que estamos tratando, transcribimos el art. 780. :

«Oposición a las resoluciones administrativas en materia de protección de menores.

No será necesaria la reclamación previa en vía administrativa para formular oposición, ante los tribunales civiles, a las resoluciones administrativas en materia de protección de menores.

La oposición administrativa por la que se declare el desamparo de un menor podrá formularse en el plazo de tres meses desde su notificación, y en el plazo de dos meses la oposición a las restantes resoluciones administrativas que se dicten en materia de protección de menores».

Por ello a la vista de estas reformas es recomendable que se evite por parte de la Administración responsable del menor, adoptar medidas definitivas, tales como un acogimiento preadoptivo o, hipotéticamente, como solución al límite, una adopción, hasta que transcurran los dos años que señala el apartado 7 del art. I72, plazo de tiempo durante el cual los padres pueden instar la revocación de la declaración de desamparo. Es un plazo que por la naturaleza jurídica de los intereses concurrentes (menores de edad), es de caducidad, no de prescripción.

Siguiendo con la Ley I/2006, el art. 49, en su punto I, señala las circunstancias que deben concurrir en el menor para declarar la situación de desamparo, con un apartado g) de cierre de las causas que indican el desamparo:

a. Abandono del menor por parte de su familia.

b. Malos tratos físicos o psíquicos al menor.

c. Trastorno mental grave de quienes ostentan la responsabilidad parental, siempre que impida o limite gravemente el adecuado ejercicio de los deberes que tales instituciones conllevan.

d. Drogadicción habitual en las personas que integran la unidad familiar, y en especial de quienes ostenten la responsabilidad parental del menor, siempre que menoscabe el desarrollo y bienestar del menor.

e. Abusos sexuales y actitudes violentas por parte de familiares o terceros en la unidad familiar del menor.

f. Inducción del menor a la mendicidad, la delincuencia, la prostitución, o cualquier otra explotación económica del menor de análoga naturaleza. 
g. Cuando se aprecie cualquier forma de incumplimiento o ejercicio inadecuado de los deberes de protección establecidos por las leyes, para guarda y educación de los menores.

Pensemos que el desamparo es la situación familiar más dramática para un menor, también debemos pensar que lo es para sus padres, por ello, consideramos de gran importancia que la ley haya establecido de forma taxativa las causas que dan lugar al desamparo, reduciendo en lo posible cualquier tipo de discrecionalidad, y dadas sus graves consecuencias y el carácter excepcional de la medida adoptada, ha de ser objeto de una interpretación restrictiva. Y aunque en el apartado g) quedan incluidas cualesquiera otras situaciones que perjudiquen claramente el desarrollo integral del menor, acaso hubiese sido oportuno haber otorgado individualidad propia a las siguientes causas:

I. La drogadicción o el consumo habitual de alcohol por parte del menor, aún con la tolerancia y permisividad de sus padres o guardadores, perjudicando gravemente con su conducta su desarrollo y bienestar.

Este texto se pudiera considerar que está integrado en el apartado d), que hace referencia a la drogadicción habitual de los miembros que componen la unidad familiar, por ello no ofrece excesivas dificultades tener en cuenta este hecho en situaciones concretas, como posible causa que permita declarar la situación de desamparo del menor. El texto de la siguiente causa con individualidad propia pudiera ser descrito a tenor del siguiente punto:

2. La convivencia en un entorno sociofamiliar que deteriore gravemente la integridad moral del menor o perjudique su desarrollo integral.

Este punto estaría pensado para aquellas situaciones en las cuales el menor materialmente está atendido, pero, sin embargo, está descuidada su formación ética y moral, o la misma no es la más adecuada para un desarrollo acorde con la edad del menor, influyendo negativamente en su educación. Sería el caso de aquellos padres o guardadores que pertenecieran a sectas o asociaciones, cuyos principios de actuación fueran una vulneración sistemática de los derechos más elementales de la persona, pudiendo causar perjuicios físicos, psíquicos, y morales al menor y ejercieran una fuerte influencia sobre sus hijos o menores a su cargo para su ingreso en las mismas, vulnerando el art. 6.I de la LO I/I996, sobre el derecho que tiene el menor a la libertad de ideología, conciencia y religión, y el punto 3, que establece el deber de los padres de cooperar para que el menor ejerza esta libertad de modo que contribuya a su desarrollo integral.

Esta conducta perniciosa de los padres respecto al menor, vulneraría también el art. I2 de la LO I/I996, que contempla la libertad ideológica, religiosa y de conciencia del menor, entorpeciendo el libre desarrollo de la personalidad, entre otros derechos contemplados en esta ley; o aquellas otras situaciones en que los padres o guardadores ejercen la prostitución en el domicilio familiar, poniendo en verdadero riesgo la formación moral del menor. Estos supuestos citados, y algún otro análogo, serían casos donde la educación y el amparo ético y moral a los hijos no es el más adecuado, faltando elementos familiares básicos para un desarrollo integral y armónico de su personalidad. En estas situaciones para proteger al menor, además de las posibles medidas de protección de carácter administrativo, se puede aplicar el art. 7.2.b), párrafo $3^{\circ}$, de la LO I/1996 $6^{6}$, en

\footnotetext{
${ }^{6}$ Art. 7.2 b), párrafo $3^{\circ}$ : «Cuando la pertenencia de un menor o de sus padres a una asociación impida o perjudique el desarrollo integral del menor, cualquier interesado, persona física o jurídica, o entidad pública, podrá dirigirse al Ministerio Fiscal para que promueva las medidas jurídicas de protección que estime necesarias».

Artículo en el cual el legislador está pensando en sectas religiosas y en aquellas asociaciones que puedan perjudicar la salud del menor con el consentimiento de sus padres, transgrediendo éstos sus deberes de
} 
concordancia con el art. 2, -principio general del interés superior del niño-, o el art. $158.4^{\circ}$ CC. que permite al Juez adoptar las medidas que estime oportunas con el fin de apartar al menor de un peligro o evitarle perjuicios. El texto de la siguiente causa con individualidad propia pudiera ser descrito a tenor del siguiente punto:

3. Cuando el menor no asista de forma continuada y sin justificación al centro escolar donde se halla matriculado, debido a la conducta negligente de los padres o guardadores, o se aprecie la ausencia de escolarización del menor, estando en edad para ello.

Si bien es cierto que la Ley I/2006 en el art. I6 «Derecho a la educación» en el punto 2 , apartados $2^{\circ}$ y $3^{\circ}$, contempla la escolarización obligatoria de los menores y obliga a la Administración a prevenir y, en su caso, erradicar el absentismo escolar, no es menos cierto que el absentismo escolar en determinados casos es un indicio bastante fiable de posibles situaciones de riesgo y desamparo. Por ello, los educadores deben seguir de cerca trayectorias de menores que faltan con regularidad a las aulas, incluso, cuando sea reiterativa y prolongada la ausencia, deben ponerlo en conocimiento de los agentes de la autoridad para averiguar los motivos que empujan al absentismo del menor. En este sentido la Ley I/2006, en el art. II8, apartados b) c) y d) clasifica infracción leve de los padres cuando no escolarizan a sus hijos, o no realizan las actividades necesarias para que estos asistan al centro escolar, o no pongan en conocimiento de los organismos públicos competentes el absentismo escolar de sus hijos, siendo sancionable esta conducta conforme al art. I20.I.a) con una amonestación por escrito o una multa de hasta 3.000 euros.

Sin embargo, tras estas conductas en principio calificadas leves, pudieran esconderse otras situaciones de verdadero abandono del menor y de dejación de uno de los deberes de la patria potestad más relevantes, y que pueden encubrir una verdadera situación de abandono del menor, en consecuencia, considero de relevancia suficiente incluir esta causa citada como motivo específico de posible apreciación de una situación de desamparo. Respecto a las sanciones a imponer a los padres por su dejación de funciones respecto a la escolarización de sus hijos, la actual ley sigue los motivos que se mantenían en la ley anterior?

Por consiguiente, independientemente de la sanción económica a los padres que llevan aparejadas estas conductas anteriores, si su incumplimiento es reiterativo con grave riesgo para el menor, -en esta situación estamos ante una infracción grave, del art. II8. 2. b)-, además de la sanción económica que conlleva de 300I euros a 60.000, se pudiera plantear la declaración de desamparo basada en el interés superior del menor.

Estimamos no obstante, que, a pesar de que estas tres causas señaladas bajo los ordinales I, 2 y 3, pueden articularse en la afirmación genérica del apartado g), consideramos que pudieran tener suficiente entidad para que se tenga en cuenta su aplicación de forma individualizada en situaciones concretas.

protección del menor, en estas situaciones se legitima al Ministerio Fiscal para que solicite las medidas que considere oportunas.

\footnotetext{
7 En la anterior Ley del Menor de I998 el art. 89.I b) contemplaba como infracción leve de los padres, «No gestionar, las personas que ejerzan la responsabilidad parental de un menor en periodo de escolarización obligatoria, la plaza escolar correspondiente sin causa que lo justifique», y en el apartado c), «No procurar, las personas que ejerzan la responsabilidad parental de un menor en periodo de escolarización obligatoria, que éste asista al centro escolar cuando dispone de plaza y sin causa justa». Y tipificaba como infracción grave, «Impedir, las personas que ejerzan la responsabilidad parental de un menor en periodo de escolarización obligatoria, que éste asista al centro escolar cuando dispone de plaza y sin causa que lo justifique», art. 89.2 c).
} 
A pesar de estas observaciones al art. 49 de la ley, éste resuelve de forma satisfactoria la declaración de desamparo. Desarrolla con acierto el art. i8 de la LO I/ı996, ya que este artículo en las actuaciones a realizar en situaciones de desamparo, se limita únicamente a señalar que se actuará conforme al art. I72 CC. y que cada entidad pública designará el órgano competente de acuerdo con sus estructuras orgánicas de funcionamiento. En este sentido, la actual Ley r/2006 simplifica y estructura mejor que la anterior los efectos que conllevará la resolución administrativa declarando el desamparo del menor.

En este sentido la ley se limita a atribuir a la Administración Pública en su condición de tutora del menor las obligaciones de la tutela. Estas obligaciones que en síntesis son: velar por el menor, alimentarlo, educarlo y proporcionarle una formación integral (art. 52.2. a), deben adoptar la medida más acorde para el menor y para la situación de los padres. Así, a la vista de los informes de los equipos técnicos competentes y atendiendo a las circunstancias del menor, y siempre teniendo en cuenta el interés de éste, son diversas las alternativas de protección que, considerando la más adecuada para el menor atendiendo a su situación personal, puede poner en marcha la Administración. De esta forma puede optar por cualquiera de las figuras jurídicas que estime oportuno:

- Acogimiento simple o permanente en familia extensa.

- Acogimiento simple o permanente en familia ajena.

- Acogimiento residencial.

- Acogimiento preadoptivo ${ }^{8}$.

- Tutela ordinaria.

- Adopción del menor.

Sin perder de vista estas alternativas, debemos insistir en lo importante que son las medidas de prevención hacia la familia del menor, ya citadas en las situaciones de riesgo del menor, una protección tanto a la familia como al menor, que puede evitar una posible situación final de desamparo. No obstante, de estas medidas que hemos reflejado y que puede adoptar la Administración, la más drástica para los padres es la adopción, que se deberá promover, en su caso, si las circunstancias de los padres, edad del menor, etc., así lo aconsejan. En estos casos, si la Administración considera al iniciar el expediente de desamparo del menor que la solución más adecuada para éste será la adopción, es muy conveniente que inicie en ese mismo momento el procedimiento de privación de la patria potestad de los padres. No olvidemos, que la declaración de desamparo conlleva aparejada la suspensión de la patria potestad, pero no la privación.

\footnotetext{
${ }^{8}$ Existe un anteproyecto de Ley de Protección a la Infancia que anunció a primeros del mes de julio la Ministra de Sanidad y Política Social, Dña. Leire Pajín, en el cual se contemplan varias novedades sobre el acogimiento. Se pretende terminar con la figura del acogimiento preadoptivo, de tal forma que los padres deberán decidir desde el principio si quieren adoptar a un hijo o solo acoger a un menor en desamparo. También contempla el anteproyecto a aquellos menores que han entrado en una situación de desamparo. Los menores de tres años pasarán, directamente, a una familia de acogida o de adopción. Los niños de tres a seis años también irán, aunque no directamente, sino «prioritariamente» a casas en lugar de centros. Los centros de menores, serán por tanto, la última opción. Se pretende así acabar con una situación dramática para los menores, que ahora esperan mucho tiempo en centros de acogida hasta que la administración soluciona su caso. La norma también contempla la posibilidad de adoptar a mayores de i8 años si éstos vivían previamente con los adoptantes en acogida, o si la convivencia de esa persona con la familia, antes de cumplir la mayoría de edad, era «estable». Se trata de que el joven, al cumplir I8 años, no pierda la protección de la familia con la que ha vivido en acogida, y de que pueda beneficiarse de todo lo que el Código Civil prevé para un hijo. La norma también regula los centros de acogida para menores con trastornos de conducta, que ahora se guían por normas autonómicas. Para mejorar estas prácticas con estos menores, el texto estipula que un menor solo puede ingresar en un centro para personas con problemas de conducta si existe un diagnóstico de un experto. Además, se establece cuándo se le puede medicar.
} 
Por otra parte, en todas las modalidades de acogimiento, se deben facilitar los derechos de visita y comunicación del menor con su familia natural (siempre que no se considere perjudicial para el menor, en cuyo caso se deben prohibir), así como la obligación por parte de la Administración de que ante la adopción de cualquier medida de las señaladas, si el menor es mayor de i2 años, debe ser oído siempre (incluso siendo menor de esta edad, si se considera que tiene suficiente conocimiento). Son numerosas las normas de nuestro Ordenamiento que así lo reflejan: el art. 9 de la LO I/i996, art. 37 de la Ley I/2006, sin olvidar el art. 92, párrafo $2^{\circ}$, y el art. I54, párrafo $5^{\circ}$, CC., entre otras.

La resolución con la medida adoptada debe ser puesta inmediatamente en conocimiento del Ministerio Fiscal, a los efectos previstos en el art. I74 CC. y también para dar cumplimiento al control judicial de los actos administrativos que expresamente ordena el art. Io6 de la Constitución. Un aspecto importante de la actual ley es que durante la instrucción del expediente de desamparo y, antes de dictar la resolución, se debe dar audiencia a los padres, tutores y guardadores del menor para que puedan comparecer en el expediente y ser oídos, art. 50.3, incluso, en el último párrafo de este punto, dispone que también pueden comparecer en el expediente después de haberse declarado la situación de desamparo del menor.

En principio, esta personación de los padres, tutores, o guardadores, durante la instrucción del expediente de desamparo del menor, para que puedan ser oídos antes de dictarse la resolución declarando el desamparo no ofrece dudas. Se trata de evitar la indefensión de las personas que tienen relación con el menor durante la tramitación del expediente. Sin embargo, la ley no contempla el plazo de tiempo durante el cual estas personas pueden comparecer en el expediente cuando ya se haya dictado la resolución declarando la situación de desamparo del menor. La ley se limita a señalar que en estos casos la Administración valorará la conveniencia de acordar el cese de la misma en los términos establecidos en los artículos 55 y 56 de la ley. El primero señala distintas causas para este cese y el segundo la reintegración en la familia. Dispone el art. 56.2 , párrafo $2^{\circ}$, in fine, que el reintegro en la familia del mayor de i 6 años, precisa su consentimiento expreso.

Llegados a este punto sobre la personación de los padres, tutores, o guardadores en el expediente una vez que se haya declarado por la entidad pública la situación de desamparo, debemos acudir a la legislación civil para determinar el plazo de tiempo durante el cual las personas legitimadas pueden comparecer en el expediente y, concretamente, a la reforma operada en el Código Civil, en el art. I72 y en los arts. 779, 780 y 78I de la LEC.

El nuevo apartado sexto del art. I72 CC dispone que: «Las resoluciones que aprecien el desamparo $y$ declaren la asunción de la tutela por ministerio de la ley, serán recurribles ante la jurisdicción civil en el plazo y condiciones determinados en la Ley de Enjuiciamiento Civil, sin necesidad de reclamación administrativa previa». Esta remisión del CC a la LEC se complementa con la reforma operada en la LEC en el art. 780, apartado I, párrafo segundo, que dispone que «la oposición a la resolución administrativa por la que se declare el desamparo de un menor, podrá formularse en el plazo de tres meses desde su notificación...».

Es interesante recalcar que en esta acción de oposición a la declaración de desamparo, la pretensión consiste en que se declare la resolución administrativa de desamparo no ajustada a derecho y se deje sin efecto, y puede basarse en demostrar que no son ciertos los hechos en que se funda la resolución, o bien, que no se han valorado correctamente los hechos y no se ajustan a la realidad, conllevando en este caso una antijurídica declaración de desamparo, o no ser procedente la medida adoptada atendiendo a las graves consecuencias del desamparo para los padres del menor.

Ahora bien, es corriente que en la resolución que declara el desamparo se decida la medida más conveniente de protección para el menor, en este caso, el plazo de oposición a la medida decretada para el menor en la resolución del desamparo, queda reducido a dos 
meses (art. 780.I, apartado segundo, último párrafo, LEC). Sin embargo, cuando ambas pretensiones se articulen de forma conjunta de manera subsidiaria o alternativa, el plazo para impugnar la resolución será de tres meses.

Conviene determinar en este momento quiénes pueden oponerse o están legitimados para oponerse a la resolución administrativa declarando el desamparo y la medida acordada. En principio, si consideramos que la consecuencia del desamparo es la suspensión de la patria potestad, parece natural que la legitimación la ostenten los padres y, por supuesto, el Ministerio Fiscal. Sin embargo, para evitar posibles acciones de indefensión atinentes a personas del círculo de la familia extensa del menor, se puede entender que la legitimación además de los padres, se debe extender a tutores ${ }^{9}$, guardadores, y en definitiva, aquellas personas que demuestren que han convivido con el menor.

Siguiendo con el comentario de la Ley I/2006, una novedad importante respecto a la ley anterior la introduce el art. 53, facultando a la Administración para declarar el desamparo en casos de urgencia. En aquellos casos en los cuales tenga conocimiento la Administración de una falta de asistencia material o moral que determinen una situación de peligro para el menor, está facultada la Administración para iniciar el expediente decretando de forma inmediata la declaración de desamparo, estando obligada a comunicarlo a los padres, tutores, o guardadores del menor y también al Ministerio Fiscal. La resolución debe estar motivada y deberá disponer la medida que se adopte respecto al menor. El expediente debe seguir su curso cumpliendo todos los trámites del art. 50. En el plazo de tres meses desde su inicio debe concluir el expediente con una resolución expresa y motivada, confirmando el desamparo y la medida adoptada, o bien, a la vista de la oposición de los padres con hechos concluyentes, declarar el cese del desamparo y de las medidas provisionales adoptadas respecto al menor, con el consiguiente archivo del expediente incoado.

El capítulo IV, Título II de la Ley, regula la situación de inadaptación del menor. Está bastante mejor delimitada que en la ley anterior. Aquélla en su art. 4 contemplaba las situaciones de riesgo, de desamparo y de inadaptación del menor. Respecto a la inadaptación del menor señalaba el último párrafo in fine de este artículo: «Se considera situación de inadaptación aquella que es declarada mediante resolución judicial, en los términos previstos por la Ley Orgánica de Reforma de la Ley Reguladora de la Competencia y el Procedimiento de los Juzgados de Menores, $y$ que exige la adopción de medidas de resocialización e inserción». Era verdaderamente complicado dotar de sentido práctico este párrafo en una ley de naturaleza civil; las medidas a adoptar en estas situaciones tienen que venir determinadas a través de los Jueces de Menores, y el espíritu y los fines que animan los mecanismos de protección y corrección en casos de inadaptación del menor, no se corresponden con los institutos jurídicos en la intervención administrativa de protección del menor, que están previstos para situaciones de riesgo o desamparo, en las cuales, la intervención de las instituciones de protección son de distinta naturaleza a las previstas en los casos de inadaptación.

Sin embargo, la actual ley regula certeramente la situación de inadaptación del menor. Señala en el art. 57 los supuestos de inadaptación del menor de i8 años y mayor de I4, respecto de los cuales los Jueces de Menores con competencia en la Comunidad de La Rioja, hubieren dictado alguna de las resoluciones que la ley detalla en los apartados: a) «medidas cautelares previstas en el art. 28 de la Ley Orgánica 5/2000, de I2 de enero, Reguladora de la Responsabilidad Penal de los Menores»; b) «adopción por sentencia firme de las medidas previstas en los apartados a) a k) del art. 7.I de la citada Ley Orgánica», y c)

\footnotetext{
9 Verdaderamente es muy difícil que una situación de desamparo se produzca en la tutela ordinaria. La misma ha tenido origen en una resolución judicial con una valoración previa del Juez sobre la situación personal y económica de los tutores del menor.
} 
«adopción de medidas de libertad vigilada de los menores o de actividades socioeducativas, en caso de suspensión de ejecución del fallo de las sentencias previsto en el art. 40.2.c) de la ley citada».

Y es el art. 58 el que otorga la competencia administrativa a la Comunidad de La Rioja, a través de la Consejería competente, en la ejecución de las medidas señalas en el apartado anterior, con la obligación de comunicar anualmente al Ministerio Fiscal y, para su traslado a los Jueces de Menores, al Presidente del Tribunal Superior de Justicia de La Rioja, los centros, los medios materiales y el personal de servicio disponible para ejecutar las medidas sobre la protección del menor en estas situaciones de inadaptación del menor.

Esta inadaptación, que puede adoptar diversas formas, como fugas del hogar, absentismo y violencia escolar, consumo de drogas, prostitución, y, en general, un desinterés y rechazo a una vida proyectada a un desarrollo armónico e integral del menor, conlleva las numerosas dificultades que se les presentan a los padres, y en su caso, a los poderes públicos, si aquellos solicitan su intervención para reconducir una situación de «inadaptación» del menor con medidas asistenciales y protectoras ${ }^{\mathrm{I}}$. El art. 60 contempla este auxilio solicitado a la Administración Pública por los padres o tutores a la Administración pública, al amparo de lo dispuesto en los artículos I54 y 268 del Código Civil. El punto 2 del art. 60 detalla las medidas que puede adoptar la Administración, conforme disponen los artículos 44 y 45 de la ley.

\section{Guarda y acogimiento}

La LO. I/1996 en su art. I9 y la Ley I/2006 en el art. 62, remiten a la constitución de la guarda cuando concurran las circunstancias previstas en el art. I72.2 C.C., que dice: «Cuando los padres o tutores, por circunstancias graves, no puedan cuidar al menor, podrán solicitar de la entidad pública competente que ésta asuma su guarda durante el tiempo necesario». Los supuestos que contempla la Ley I/2006 en los cuales la Comunidad Autónoma de La Rioja asumirá la guarda de los menores, vienen perfectamente delimitados. El art. 62.1 ${ }^{\circ}$ contempla la tutela automática o ex lege, por ministerio de la ley, para los menores en desamparo. El punto $2^{\circ}$ contempla una guarda administrativa cuando ésta viene requerida por solicitud de los titulares de la patria potestad, o en su caso, los tutores, por imposibilidad de atender a los menores por causas ajenas a su disposición. Y el punto $3^{\circ}$, la guarda legal, cuando la autoridad judicial así lo acuerde en determinados casos que dispone la Ley Orgánica 5/2000, de I2 de enero, de Responsabilidad Penal de los Menores, y en determinadas situaciones de crisis matrimonial, nulidad, separación o divorcio que, por interés del menor, así lo estime el Juez hasta la resolución final del procedimiento. Con buen criterio la ley extiende la guarda legal cuando en un procedimiento civil o penal y durante la sustanciación del mismo, detecte el Juez un incumplimiento de los padres de los deberes de la patria potestad.

Io Estudiando este punto, Aparicio Blanco (200I, 83-9I), el cual cita diversos autores que han tratado esta cuestión, se pregunta, «¿Puede considerarse desamparado a efectos legales los menores inadaptados, rebeldes, autores de comportamientos antisociales - no delictivos- que con su actitud están poniendo en peligro su formación al dificultar el cumplimiento por los padres de los deberes de protección y encontrándose, de hecho, en riesgo de marginación social y delincuencia?». Su respuesta a la vista del texto del art. I72.I es negativa.

Debemos recordar que la declaración de desamparo lleva aparejada la suspensión (art. I72.I C.c.) de la patria potestad de los padres. Nos podemos imaginar cómo entenderán unos padres que están haciendo lo indecible por prestar todo tipo de asistencia a su hijo, y que por mal del comportamiento de éste, por una inadaptación social, se les prive del ejercicio de la patria potestad sobre su hijo. Se puede destacar la doctrina del Tribunal Constitucional en este sentido, inclinándose por otorgar al concepto jurídico de desamparo, una interpretación restrictiva. Cfr. STC. I9 de octubre de 1993. En esta línea numerosas sentencias posteriores de Audiencias Provinciales, entre otras, la SAP. de Sevilla, $n^{\circ}$ 226/99, de 3 de marzo. 
Situación que el Juez conviene que ponga en conocimiento de la Administración, para que, a través del auxilio y cooperación de los equipos técnicos competentes, pueda determinar si es transitoria o definitiva la situación, porque en función del dictamen de los técnicos la solución que se debe adoptar para con el menor será diferente.

En definitiva, el art. 62 es bastante más preciso que el anterior art. 54 de la Ley de I998. Aquél alude a todos aquellos supuestos en que, independientemente de la voluntad de los padres, sea la Administración pública, y el Juez, en su caso, quien asuma la responsabilidad de protección del menor cuando así lo considere oportuno, impidiendo posibles situaciones de desprotección que no estuvieran contempladas en la ley.

La guarda por parte de la Consejería competente de Servicios Sociales de la Comunidad de La Rioja, comprende los mismos deberes y facultades de quien tiene atribuida la patria potestad sobre los hijos, por lo tanto, las personas (acogimiento familiar) o la institución pública (acogimiento residencial) que recibe temporalmente a un menor. Deberá velar por él, tenerlo en su compañía, alimentarlo, educarlo y procurarle una atención y formación integral. No obstante, el ejercicio de la guarda es diferente en los distintos supuestos del artículo 62 citado. Tanto en la guarda administrativa como en la guarda legal es una actuación por parte de la Administración, de menor intensidad que la tutela automática $o$ ex lege, porque en las dos primeras situaciones de desprotección del menor, se tienen suficientes indicios o datos para considerar la transitoriedad de la situación y la posibilidad de reintegrar al menor posteriormente en su núcleo familiar, una vez superadas las causas que han motivado la intervención de la Administración, o, en su caso, de la Autoridad judicial; en caso contrario, si esa desprotección se presenta con un cariz de permanencia y de imposible solución por su familia natural o personas que tienen a su cargo la guarda del menor, y concurren las causas previstas, procederá declarar el desamparo con todas las consecuencias previstas.

El ejercicio de la guarda viene establecido en el art. 63 de la ley, que en su punto I reproduce literalmente el art. I72.3 CC que distingue entre acogimiento familiar o acogimiento residencial. Se debe dar prioridad al acogimiento familiar, y como dice el punto 2 del art. 63, el internamiento del menor en centros residenciales tendrá carácter provisional y será subsidiario del acogimiento familiar. Por ello, siempre atendiendo al interés superior del menor, se debe procurar su reintegración a su núcleo familiar natural lo antes posible. La Ley 2I/I987, de II de noviembre, que modificó determinados artículos del Código Civil referentes a la adopción, sólo contempló la posibilidad del acogimiento familiar, no obstante, la LO I/1996 incorporó al Código Civil a través del art. I73 bis, las distintas clases de acogimiento, reproducidas también en la Ley I/2006.

Por consiguiente, respecto a los tipos de acogimiento no hay ninguna novedad en la ley en este apartado, como no sea la responsabilidad de la Administración por los daños causados o sufridos por los menores que estén bajo su guarda. La ley, en el art. 64 referido al contenido de la guarda dispone que esta responsabilidad sea exigible conforme a lo dispuesto por las leyes para la responsabilidad patrimonial de las Administraciones públicas cuando actúen en relaciones de Derecho privado. También concede la ley entidad propia a la emancipación o habilitación de edad del menor como causa de cese del acogimiento. Está bien la precisión de la Ley I/2006 en este punto que completa el art. I73.4 CC sobre el cese del acogimiento.

Respecto a la formalización del acogimiento derivado de una declaración de desamparo, éste no debe superar el plazo de I5 días desde que se hubiere declarado (art. 67.3 de la ley). También se contempla, siempre en interés del menor, la posibilidad de modificar la modalidad del acogimiento una vez acordado y ejecutado, en este caso habrá que proceder conjuntamente con el cese del existente y la constitución del procedente, siempre con la obligada reserva de actuaciones. Así lo dispone el art. 78.3. 
Cuando el acogimiento venga derivado de la guarda a instancia de los padres o tutores, hay que tener presente la modificación que ha sufrido el apartado 3 del art. I72 CC por la Disposición final primera del la Ley 54/2007, de 28 de diciembre, de adopción internacional, que dispone que los padres o tutores podrán oponerse en el plazo de dos meses a la resolución administrativa que disponga el acogimiento, cuando éstos estimen que la decisión acordada no es la más conveniente para el interés del menor.

Como ya hemos señalado anteriormente, una novedad interesante que introduce la Ley i/2006 es el art. 53, que recoge la declaración de desamparo en casos de urgencia. También el art. 76 contempla esta posibilidad de acogimiento, de manera que mientras no se dicte una declaración definitiva sobre el desamparo, se puede proceder a un acogimiento de urgencia, tanto familiar como residencial, atendiendo siempre a las necesidades y circunstancias del menor. Tiene carácter transitorio, por consiguiente, no es necesario cumplir los requisitos ni formalidades legales de esta medida. A pesar de esto, sí que impone la ley la obligación de comunicarlo al Ministerio Fiscal y, si es posible, a los padres, tutores, o guardadores. Notificación que debe realizarse dentro del plazo de 48 horas, acompañando a esta notificación la declaración de desamparo de urgencia. Este acogimiento provisional, hasta tanto se dicte la resolución sobre el desamparo del menor, no podrá exceder de tres meses.

Respecto a las modalidades del acogimiento, el art. 80 reproduce el art. I73 bis CC, pero se separa de este texto legal en el plazo que la Ley I/2006 ha fijado para presentar por parte de la entidad pública la propuesta de adopción al Juez en el acogimiento preadoptivo, esto es, el período de tiempo de adaptación del menor con la familia adoptante, estableciendo la ley un plazo de adaptación máximo de 9 meses desde la constitución de aquél, frente al plazo de un año que fija el Código Civil.

Pero las novedades más interesantes de la nueva ley en el acogimiento de menores se corresponden con el acogimiento familiar profesionalizado (art. 82) y el acogimiento en hogar funcional (art. 83). En la anterior ley se contemplaba la remuneración de los acogedores por los gastos de mantenimiento del menor. La nueva ley completa este punto y dispone que se considerará acogimiento profesionalizado cuando exista remuneración a los acogedores, y éstos, percibirán tanto los gastos de alimentación como los gastos de educación del menor. Otro aspecto interesante respecto al acogimiento lo encontramos en el art. 83, ya que el acogimiento simple y el permanente se podrán desarrollar en un hogar funcional, siendo dependientes de la Administración de la Comunidad Autónoma de La Rioja, o en su caso, dependientes de Entidades Locales o de Instituciones colaboradoras de integración familiar. No obstante, la inspección y control de estos hogares funcionales queda atribuido a la Consejería competente de Servicios Sociales de la Comunidad de La Rioja.

Otra novedad importante son los criterios para seleccionar a los acogedores, incorporados en el art. 84, destacando el punto 3 que señala que tanto los acogedores profesionales y los responsables de los hogares funcionales, habrán de contar previamente a la formalización del acogimiento, con la declaración de idoneidad para el desempeño de sus labores, y también se exige esta declaración previa en el acogimiento preadoptivo, siendo seleccionados atendiendo a los criterios previstos para la adopción (art. 84.4).

Los criterios de selección vienen desarrollados en el art. 48 del Decreto io8/2007, de 27 de julio, por el que se aprueba el Reglamento sobre intervención de las Administraciones Públicas de La Rioja en la protección y guarda de menores, citamos este artículo por los criterios rigurosos que señala para seleccionar a los acogedores, no queremos ser exhaustivos, y citamos únicamente los epígrafes de los criterios que contempla: $\mathrm{I}^{\circ}$ ) Con relación a las características personales de los solicitantes; $2^{\circ}$ ) Con relación a la capacidad educativa y a la competencia parental; $3^{\circ}$ ) Con relación a las 
circunstancias socioeconómicas, y $4^{\circ}$ ) En relación con el menor y con la familia biológica y la competencia parental.

Cuando no sea posible el acogimiento familiar, incorpora la ley el acogimiento residencial (arts. 87 a 90). Se corresponde con el ingreso del menor en un centro residencial titularidad de la Comunidad Autónoma o de una institución pública o privada colaboradora en la protección de menores, siendo en este último supuesto, responsable del menor el Director del Centro o Institución (en ambos casos bajo la supervisión tanto de los órganos competentes de la Comunidad, como del Ministerio Fiscal).

Pero sin duda alguna, la novedad más importante en la ley en sede de acogimiento, es el art. 9I, que contempla «acogimientos residenciales especiales», para aquellos menores que, necesitando protección y concurriendo determinadas circunstancias, impiden su ingreso en un centro residencial normalizado. Son menores que presentan determinadas patologías de carácter físico o psíquico, problemas de drogadicción, o problemas de integración y socialización, necesitando equipos técnicos especializados para que el acogimiento, además de cumplir su función básica, esto es, la protección del menor para evitar en muchos casos el desamparo, pueda resultar eficaz su internamiento.

\section{Adopción y Registro de Protección de Menores}

La regulación de la adopción en el Título IV de la Ley I/2006 es exhaustiva y completa. Se ha mejorado sensiblemente el texto respecto a la Ley de I998, destacando, principalmente, una mayor seguridad jurídica en una materia tan importante y sensible como es la adopción de menores.

Los principios generales vienen determinados en el art. 92, capítulo I, «Corresponde en exclusiva a la Administración de la Comunidad Autónoma de La Rioja, la gestión del procedimiento de adopción en el ámbito territorial de La Rioja, que comprende la recepción y tramitación de solicitudes, la declaración de idoneidad de los solicitantes, la selección de adoptantes y la propuesta de adopción ante la Autoridad judicial competente».

Describe este artículo las amplias facultades que tiene la Comunidad Autónoma de La Rioja en el ámbito de la adopción, que comprende toda la gestión del procedimiento, desde la recepción de los documentos hasta la propuesta de adopción ante el Juez para que dicte la resolución.

Destaca el requisito del art. 94.2 sobre información y formación a los futuros padres adoptantes para la adopción, que dispone que los solicitantes deben haber completado un proceso de formación, incluyendo las responsabilidades que asumen como padres y las particularidades frente a la paternidad biológica. No haber completado este proceso de formación es una de las causas que dispone la ley para excluir la solicitud. Incorpora la Ley el período de tiempo de convivencia que deben acreditar las parejas de hecho para acceder a la adopción: un mínimo de tres años. En este sentido es imperativo el art. 96 c), el cual, sobre los «criterios de exclusión de solicitudes» señala: «En caso de adopción conjunta, los solicitantes que no acrediten tres años de convivencia», y el Decreto 3I/2007, indica que se procederá al archivo de la solicitud de adopción con carácter previo a la valoración de idoneidad, cuando, en caso de adopción conjunta, los solicitantes no acrediten tres años de convivencia. Como requisito previo a la admisión a trámite de la solicitud de adopción, ambos solicitantes habrán de completar el proceso de formación acerca de las responsabilidades parentales, el contenido e implicaciones de la adopción, y sus particularidades frente a la paternidad biológica, así lo dispone el art. 94.3 de la Ley y el art. 7.2 del Decreto citado. 
Un juicio positivo merece el plazo de tiempo que dispone la Administración para resolver sobre la idoneidad de los adoptantes. La idoneidad hace referencia a la aptitud de los solicitantes para desempeñar las funciones parentales, teniendo en cuenta sus circunstancias personales, sociales, económicas y familiares, así como los motivos que les han llevado a solicitar la adopción. En este sentido, el art. 97 de la Ley i/2006, se presenta con una pormenorizada y exhaustiva relación de criterios de valoración que han sido desarrollados reglamentariamente en el art. 22 del Decreto 3I/2007, de 25 de mayo, para declarar, en su caso, la idoneidad de los adoptantes, cuyos efectos se contemplan en el art. 99 de la ley. La declaración de idoneidad se inscribirá en el folio de sus titulares en el Libro Segundo del Registro de Protección de Menores de La Rioja.

Si tenemos en cuenta que los posibles padres adoptantes se someten a unos criterios muy rigurosos para valorar su disposición, sus actitudes y aptitud para la adopción, es saludable que la resolución no se dilate en el tiempo y se evite mantener en una situación de incertidumbre a los solicitantes. Por ello establece la ley que no se debe prolongar más de seis meses el proceso de valoración de la idoneidad, estimando, que, si la Administración ha guardado silencio se considera negativa la valoración efectuada. En su caso, notificada a los adoptantes la valoración negativa antes de este plazo, la Administración debe motivar su resolución y exposición de las causas que le han llevado a esa decisión.

Si la declaración de idoneidad es positiva, los futuros adoptantes no alcanzan la constitución de derecho en relación al hecho mismo de la adopción, si bien es cierto que es un requisito previo e inexcusable para que puedan acceder a una adopción, pero la idoneidad puede revisarse si cambian las circunstancias de los solicitantes; ahora bien, si las circunstancias permanecen inalterables, la vigencia de la declaración de idoneidad tiene un período de tiempo de tres años para acceder a la adopción. Si durante este período no han concurrido las circunstancias favorables para hacer efectiva una adopción, la resolución ha caducado, y, si los futuros adoptantes quieren seguir optando, deberán pasar una nueva valoración de todos los aspectos que señala la ley (art. 99 en concordancia con el art. 96.2). También en este apartado, es interesante el silencio de la Administración. Si, caducada la resolución, los solicitantes acceden a un nuevo procedimiento de valoración de la idoneidad, se debe resolver en un plazo de tres meses, y si durante este período de tiempo se produce el silencio de la Administración, se considera que la declaración de idoneidad ha sido renovada.

Otra novedad importante en la ley consiste en ofrecer identidad propia a la adopción de los menores con características, circunstancias o necesidades especiales (art. IO2). Considera en este grupo a los grupos de hermanos, a los mayores de seis años, a los menores que sufran discapacidades o enfermedades físicas o psíquicas, y a quienes han sufrido experiencias traumáticas como pudiera ser maltrato infantil. Además de estas circunstancias específicas, incluye otras generales, tal como aquellos menores que tengan dificultades para una integración social, causadas bien por circunstancias personales del propio menor o circunstancias sociales de su entorno. El desarrollo de estas circunstancias especiales o necesidades presentes en el menor vienen desarrolladas en el art. 32.2 del Decreto 3I/2007, de 25 de mayo, Reglamento de Intervención Administrativa en Materia de Adopción.

Y en esta línea sobre determinadas características especiales de los menores hay que tener en cuenta una novedad importante en la ley. El rechazo injustificado de un menor para su adopción, tendrá una importante consecuencia para los solicitantes, como es que quedarán excluidos del Registro para futuras adopciones. No obstante, la ley hace una excepción, indica que si este rechazo es debido al estado de salud del menor, se entenderá como una «eximente» para los solicitantes, considerando justificado el rechazo del menor.

El art. Io3 de la ley establece las condiciones que debe reunir el adoptante. En su punto 2 señala que estos criterios se establecerán reglamentariamente, teniendo siempre 
presente el superior interés del menor (véase al respecto los arts. 36 y 37 del Decreto 3I/2007). Sin exclusión previa alguna en cuanto a la composición del género de la pareja, entendemos que se preferirán las adopciones por matrimonios o uniones de parejas de hecho heterosexuales que puedan ofrecer al menor un hogar estable y las necesidades que exija su desarrollo integral, que el medio familiar reúna las condiciones adecuadas, tanto en los solicitantes como respecto a los miembros que convivan con ellos; también respecto a la situación socioeconómica, habitabilidad de la vivienda, infraestructura de la zona de residencia, disponibilidad de tiempo para su educación, tanto si son cónyuges, como personas que convivan maritalmente de hecho, y especialmente que tengan una relación de pareja estable y positiva, aunque entendemos que lo realmente importante es articular estos requisitos con la capacidad para ejercer las obligaciones que asumirán los adoptantes, es decir, las referidas al ejercicio de la patria potestad.

La nueva ley completa la adopción dedicando el Capítulo III del Título IV a la adopción internacional. Mientras la ley anterior dedicaba a este aspecto únicamente un artículo (art. 67), la actual la contempla en los artículos IO4 a III, destacando la regulación de las entidades colaboradoras de adopción internacional. La habilitación de las mismas corresponde a la Administración de la Comunidad Autónoma de La Rioja, así como la regulación de sus funciones, sus obligaciones, la inspección y control de las mismas y posibles sanciones. Define la ley qué son las instituciones colaboradoras, y hace una remisión reglamentaria al Decreto 31/2007, de 25 de mayo, respecto a los requisitos que deben cumplir para su habilitación, procedimiento de autorización de las instituciones, y la periodicidad de inspección y control de las mismas para asegurarse del cumplimiento de sus funciones en exclusivo interés del menor.

También queremos destacar en la ley la creación y regulación del registro de protección de menores. Es un registro central y único para toda la Comunidad de La Rioja, tiene carácter reservado y no constitutivo, y debe garantizar la seguridad jurídica derivada de la actuación administrativa de las materias reguladas en la ley. Lo componen tres libros distintos: el $\mathrm{I}^{\mathrm{o}}$, menores sometidos a protección; el $2^{\circ}$, menores solicitantes de acogimiento o adopción, y el $3^{\circ}$, de entidades colaboradoras de integración familiar y de adopción internacional. Se garantiza por ley la confidencialidad y la obligación de reserva de las inscripciones practicadas en los libros $\mathrm{I}^{\mathrm{O}}$ y $2^{\circ}$, reservado su acceso únicamente al Ministerio Fiscal y Jueces y Tribunales, por el contrario, el contenido del libro $3^{\circ}$, será público para todas aquellas personas que tengan interés sobre las entidades colaboradoras. La organización y funcionamiento del Registro es objeto de desarrollo reglamentario en el Decreto 3I/2007, de 25 de mayo.

Finaliza la ley con una extensa relación de las conductas tipificadas leves, graves y muy graves, la prescripción de las mismas atendiendo a su calificación y las consiguientes sanciones conforme a su graduación. La potestad sancionadora corresponde a la Administración de la Comunidad de La Rioja, a través de la Consejería competente, quedando reservada la resolución de las conductas tipificadas como muy graves al Consejo de Gobierno. Por último, llama la atención la posibilidad de publicación en el Boletín Oficial de La Rioja de las sanciones firmes que sean consideradas graves y muy graves. El argumento que justifica en su caso la publicación sería el de dar a conocer la ejemplaridad de la sanción en previsión de evitar futuras conductas infractoras.

Cierra la ley con dos Disposiciones adicionales, estableciendo en la segunda la protección a los menores extranjeros no acompañados. Conforme a la legislación en vigor, señala la ley que, declarado en desamparo el menor, deberá la Administración de La Rioja solicitar a la Administración del Estado la pertinente autorización de residencia, proporcionando de inmediato al menor la asistencia que precise. 


\section{Anexo: Enumeración de los derechos y deberes de los menores en los Centros de acogida}

A modo de Anexo (aunque en el Decreto I08/2007, de 27 de julio, se aprueba el reglamento sobre Intervención de las Administraciones Públicas de La Rioja en la protección y guarda de los menores, y se recoge el régimen de los centros de acogida de protección de menores, concretamente en el Título II, Capítulo IV, «Régimen de los centros de acogida»), independientemente de las normas del Decreto, queremos especificar aquellos derechos y deberes que consideramos que deben asumir los menores en estos centros:

Los derechos de los menores serían:

I. A ser atendidos sin que pueda prevalecer discriminación alguna por razón de nacimiento, raza, sexo, religión, opinión o cualquier otra condición o circunstancia personal o social.

2. A recibir un trato digno y respetuoso tanto por el personal del centro como por los demás menores residentes.

3. Al secreto profesional y la utilización con la conveniente reserva de su historial de todos los datos que en el mismo consten.

4. Siempre que sea adecuado para el menor, la conveniencia de mantener relaciones con sus familiares y recibir visitas en el centro.

5. A tener cubiertas suficientemente las necesidades esenciales de su vida cotidiana, que le permitan el adecuado desarrollo personal.

6. Respeto a su intimidad personal y creencias religiosas en el contexto educativo que debe regir en el Centro.

7. A disfrutar en su vida diaria de un sistema ordenado de actividades, que le permita periodos equilibrados de sueño, ocio y actividad.

8. A conocer su situación legal en todo momento y a ser oídos si son mayores de doce años, o en su caso, si tuvieren suficiente juicio, en aquellas decisiones que tengan trascendencia personal de indudable importancia.

En ningún caso y por mandato imperativo del art. II, párrafo $3^{\circ}$, de la LO I/I996, estos derechos deben quedar afectados por falta de recursos sociales básicos.

Las obligaciones de los menores serían:

I. Respetar y cumplir las normas que regulen el funcionamiento del Centro, y mantener una convivencia adecuada dentro de él. Centro.

2. Respetar la dignidad y función de cuantas personas trabajen o vivan en el

3. Desarrollar con dedicación y aprovechamiento las actividades escolares, laborales o cualesquiera que estén dirigidas a su desarrollo y formación integral.

4. Obedecer al personal educador del centro en su labor educadora y formativa. Estos podrán corregir razonable y moderadamente a los menores con medidas pedagógicas y con fines siempre educativos.

De todas formas, y aunque la Ley y el Decreto io8/2007 no los contemple, es aconsejable que estos derechos y obligaciones se tengan en cuenta y se apliquen en el Centro de Acogida para un funcionamiento adecuado del mismo, respetándose de forma 
rigurosa tanto los derechos de los menores, como imponiendo las obligaciones inherentes a su estancia.

Quiero terminar esta ponencia dejando constancia de la opinión favorable que me merece esta Ley. Tiene una alta e importante función que cumplir: atender al colectivo de personas más vulnerables de la Comunidad Autónoma de La Rioja, los menores desprotegidos que se encuentran en situaciones de riesgo o en desamparo.

\section{Bibliografía}

AA.VV. (200I): Aspectos Jurídicos de la Protección del Menor, Junta de Castilla y León.

Alfonso Rodríguez, Ma E. (I995): «La guarda de hecho: su relación con otros institutos jurídicos de protección de menores», Actualidad Civil I7.

Alonso PÉREZ, M. (I997): «La situación jurídica del menor en la Ley Orgánica I/I996, de I5 de enero, de Protección Jurídica del Menor de Modificación del Código Civil y de la LEC: Luces y sombras», Actualidad Civil I, p.20.

Aparicio Blanco, P. (200I): «La protección del menor inadaptado y su conflicto social», en Sáez Hidalgo, I. (coordinador), Aspectos Jurídicos de la Protección del Menor, Junta de Castilla y León.

Benito Alonso, F. (I997): «Actuaciones de riesgo y desamparo de menores. Tutela automática y guarda», La Ley 360.

Caballero Sánchez-Izquierdo, J. Ma . (I995): «Instituciones para la protección de menores», Actualidad y Derecho I6.

De Pablo Contreras, P. (I999): «'Situaciones de desamparo’ y ‘situaciones de riesgo’ de desprotección social de los menores en la Ley Orgánica I/I996, de I5 de enero, de Protección Jurídica del Menor», en Pérez Álvarez, M. A. (director), La desprotección social de los menores y las instituciones de amparo reguladas en la Ley Orgánica de Protección del Menor, Universidad de La Coruña. Servicio de Publicaciones.

Del Moral García, A. (I998): «Derechos humanos, menores y Ministerio Fiscal», La Ley 4687.

Del VAs GonZÁlez, J. Ma (2009): Instituciones jurídicas de protección del menor en el derecho civil español, Madrid: Colegio de Registradores de la Propiedad y Mercantiles de España, Centro de Estudios.

FERNÁNDEZ, E. (I995) «Tutela, guarda y acogimiento en la Ley 21/I987 (Aspectos sustantivos y procesales)», Actualidad Civil Vol. I $\mathrm{n}^{\circ} 2$.

FERnÁNDEZ GonZÁLEZ, Ma B. (2000): «Visión general del acogimiento familiar», Actualidad Civil 46.

García CANTERo, G. (20I0): «El enigmático artículo I72 CC español y sus secretos familiares», Revista Jurídica del Notariado 76 .

GonZÁlez LÁZARo, I. (Coord.) (2002), Los menores en el Derecho español, Madrid: Tecnos.

LinACERo de LA Fuente, M. (200I): Protección Jurídica del Menor, Madrid: Montecorvo.

Magro Servet, V. (Coord.) (2005): Guía práctica del menor y de la violencia de género y doméstica, Madrid: La Ley.

MARTínEZ DE AguiRRE, C. (I992): «La protección jurídico-civil de la persona por razón de la menor edad», Anuario de Derecho Civil 4.

MARTín LÓPEZ, Ma T. (Coordinadora) (200I): La protección de los menores: derechos y recursos para su atención, Madrid: Cívitas.

Moreno Flórez, R. Ma (I999): «Comentario al artículo I72 del Código Civil», en Rams Albesa, J. (coordinador), Comentarios al Código Civil, Barcelona: José María Bosch.

Murillas Escudero, J. M. (2003): «Notas a la Ley 4/1998, de i8 de marzo, del Menor, de la Comunidad Autónoma de La Rioja», Revista de Jurisprudencia, TSJ, AP y Otros Tribunales 2.

O’Callaghan Muñoz, X. (I996): «Personalidad y Derechos de la Personalidad (Honor, intimidad e imagen) del menor, según la Ley de Protección del Menor», La Ley 4077.

Padial AlbÁs, A. Ma y ToldrÁ RocA, Ma D. (Coords.) (2007): Estudios jurídicos sobre la protección de la infancia $Y$ de la adolescencia, Valencia: Tirant lo blanch.

PÉREZ ÁlVAREZ, M. (1989): La nueva adopción, Madrid: Cívitas. 
PÉReZ MARTín, A. J. (I998): «Adopción, acogimiento, tutela y otras instituciones de protección de menores», Valladolid: Lex Nova.

QuiÑónez Escámez, A., Ortuño Muñoz, P., Calvo Babío, F., (Coords.) (2005): Crisis matrimoniales. Protección del menor en el marco europeo, Madrid: La Ley-Actualidad.

RAMAS VARO, Ma L. (200I): La protección legal de la infancia en España, Madrid: Consejo Económico y Social.

Rivero Hernández, F. (2000): El interés del menor. Madrid: Dykinson.

Rodríguez AlmadA, H. (2006): Maltrato y abuso sexual de menores. Una revisión crítica, Granada: Comares.

Romero Coloma, A. Mª (2006): Derecho a la libertad religiosa del progenitor frente al beneficio del hijo menor: problemática jurídica, Barcelona: Bosch.

Ruiz-Rico Ruiz, J. M. (I988) «La tutela 'ex lege', la guarda y el acogimiento de menores», Actualidad Civil, I, nº 2 y 3.

Serrano Ruiz-Calderón, M. (Coord.) (2007): Los menores en protección, Madrid: Difusión Jurídica y Temas de Actualidad.

VALlAdARES GASCón, E. (I990): «La tutela de los menores en relación con el concepto legal de desamparo», en Ministerio de Justicia, Centenario del Código Civil II, Madrid: Ministerio de Justicia.

ViCEnT López, C. (I999): «Notas sobre el acogimiento preadoptivo en La Ley I/I996, de I5 de enero, de Protección Jurídica del Menor», Revista General del Derecho 85.

Vivancos SÁNCheZ, M. (2000): «Constitución de la tutela automática tras la declaración de desamparo», Actualidad Civil 48.

\section{Legislación}

Ley I/2006, de Protección de Menores de La Rioja (BOR 9-03-2006).

Decreto 3I/2007, de 25 de mayo, por el que se aprueba el Reglamento de Intervención Administrativa en Materia de Adopción (BOR 29-05-2007).

Decreto 108/2007, de 27 de julio, por el que se aprueba el Reglamento sobre intervención de las Administraciones Públicas de La Rioja en la protección y guarda de los menores (BOR 3I-07-2007).

Ley 4/I998, de I8 de marzo, del Menor de La Rioja (Derogada) (BOR 24-03-I998). 